\author{
MINERALOGIA POLONICA \\ 10.2478/v10002-007-0007-8 \\ PL ISSN 0032-6267 \\ Vol. 37, No 1, 2006
}

\title{
WŁODZIMIERZ WOJCIECH KOWALSKI
}

1932-2005

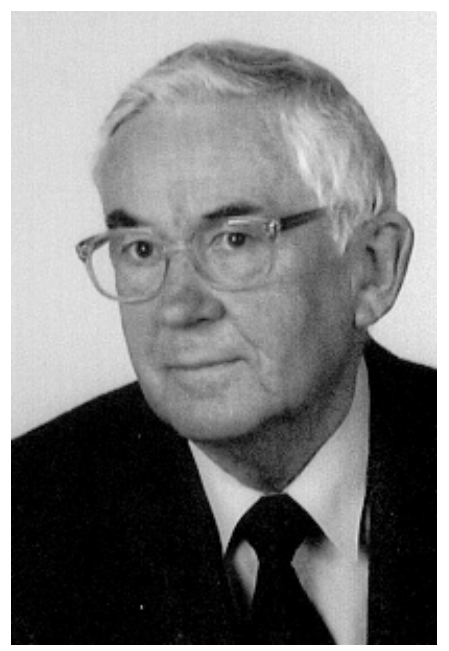

The 10th of August, 2005, marks a next loss for the mineralogical community in Poland. On that day, at the age of 73, passed away Włodzimierz W. Kowalski, a retired professor of the Warsaw University and a founding member of the Mineralogical Society of Poland.

Włodzimierz Wojciech Kowalski was born on $19^{\text {th }}$ April, 1932, in Gniezno. He spent the difficult years of war and Nazi occupation in Poznań, where in 1951 he started geological studies at the Poznań University. A year later, due to reorganization of geological education in Poland, the whole mineralogical science section was moved to Warsaw, to the newly-formed Faculty of Geology of the Warsaw University. For the next three years, still being a student, he performed assistant's duties there. He graduated in 1956, specializing in mineralogy and geochemistry. In the same year he was employed by the Warsaw University, where he passed every stage of his academic career, from assistantship to full professorship. In 1964 he obtained a Ph.D. degree, based on the dissertation "Trace elements in feldspars of the Sudetic granitoids", written under the supervision of Prof. Antoni Polański. Ten years later he earned his post-doctoral degree in Earth sciences presenting the dissertation "Geochemistry, mineralogy and origin of the Lower Silesian barite deposits and occurrences". In 1985 he was nominated extraordinary professor and in 1994 ordinary professor, working all the time until his retirement in 2002 at the Faculty of Geology of the Warsaw University.

Prof. W. Kowalski's scientific interests were very broad and included different mineralogical and geochemical problems. His more important research included the following topics: mineralogy and geochemistry of Strzegom pegmatites, barite and sulphide mineralization in the Sudety Mts, petrology and mineralogy of the Carboniferous sediments in the Polish Lowlands, genesis of the native sulphur deposits of the Carpathian Foredeep. He was one of the initiators of stable isotope research in Poland, especially of sulphur and oxygen isotopes. He was also interested in geological aspects of material history, investigating, for example, applications of terra sigillata tablets in the past centuries in medical treatment, or the origin of construction stones used in the Cistercian abbey in Wąchock and the Royal Castle in Warsaw. In the last years of his activity, Prof. Kowalski was busy studying potential sources of rare earth elements in 
Poland. His research was focused mainly on the possibilities of obtaining rare earth concentrates from phosphogypsum waste left over in apatite processing, and on microbiological utilization of phosphogypsum applying organic industrial waste.

Prof. Kowalski held several important posts at the Warsaw University and in other institutions. In the years 1975-1981 he was a Vice-Dean of the Faculty of Geology, and in the period 1982-1985 a Vice-Chancellor of the Warsaw University. For many terms, between 1986 and 2001, he was the Head of the Institute of Geochemistry, Mineralogy and Petrology at the Faculty of Geology. He was an appreciated expert in the former Ministry of Education, High Scholarship and Technics, the National Education Ministry and the Polish Parliament of the 9th term. He also took part in the opposition-government round table conference. A proof of prof. Kowalski's professional achievements was his election as a member of the Committee of Geological Sciences of the Polish Academy of Sciences and the Committee of Mineralogical Sciences of the Polish Academy of Sciences. In the period 1981-1989 he was the Vice-Chairman of the latter committee.

As an active member of the Mineralogical Society of Poland, he performed several functions: he was a member of the Main Board and a member of the "Mineralogia Polonica" Editorial Board.

Prof. Kowalski was a talented lecturer, devoting a great passion and personal involvement to his didactic duties. His "Mineralogy with crystallography and crystal optics", "Ore microscopy" and "Isotope geochemistry" lectures, proceeded by numerous laboratory exercises, were very popular among students. He showed also great favours in educating young scientists: he promoted seven Ph.D. dissertations and supervised over 40 M.Sc. theses. On several occasions he also reviewed doctoral and post-doctoral dissertations as well as academic achievements in professorship nomination procedures.

In appreciation of his numerous scientific, didactic and organizational achievements he was awarded many times by the Minister of High Education and the Chancellor of the Warsaw University. He was also honoured with many national and resort decorations, including the Cavalier Cross of the Polonia Restituta order, the Gold Cross of Merit and the "Distinguished Teacher" title.

Prof. Kowalski was paid last respect by numerous grieving friends and colleagues, and was put to rest at the Powązki Cemetery in Warsaw.

Jan PARAFINIUK 


\section{SELECTED PAPERS OF WŁODZIMIERZ W. KOWALSKI}

KOWALSKI W., WALEŃCZAK Z., 1957: Rubid w skaleniach pegmatytów sudeckich. Arch. Miner. 21, 2, 427-459.

KOWALSKI W., 1967: Geochemia potasu, sodu, wapnia, rubidu, ołowiu, baru i strontu w granitoidach sudeckich i ich pegmatytach. Arch. Miner. 27, 1, 53-244.

KOWALSKI W., 1967: Badania kamieni budowlanych w zabytkach Wąchocka. Bibl. Muzealnictwa $i$ Ochrony Zabytków 19, B, 215-232.

KOWALSKI W., 1970: Die Verteilung einige Haupt- und Spurenelemente in Feldspaten der Strzegom Pegmatite. Freib. Forschungsh. C 270, 133-150.

KOWALSKI W., WIEWIÓRA A., 1973: Terra Sigillata. Pr. Muz. Ziemi 21, 2, 3-57.

KOWALSKI W., SZPILA K., WYRWICKI R., 1974: Konkrecje barytowe w iłach serii poznańskiej ze Stabłowic koło Wrocławia. Kwart. Geol. 18, 2, 370-379.

KOWALSKI W., MAZUREK Z., MAZUREK A., 1976: Geochemiczno-mineralogiczna charakterystyka marmurów dolomitowych w Rędzinach. Kwart. Geol. 20, 1, 21-37.

KOWALSKI W., 1976: Geochemia, mineralogia i geneza dolnośląskich złóż i wystąpień barytowych. Cz. I. Arch. Miner. 32, 2, 3-100.

KOWALSKI W., 1977: Geochemia, mineralogia i geneza dolnośląskich złóż i wystąpień barytowych. Cz. II. Arch. Miner. 33, 1, 107-172.

KOWALSKI W., 1977: Badania składu izotopowego tlenu w dolnośląskich barytach. Prz. Geol. 8-9, 450-454.

KOWALSKI W., KARWOWSKI Ł., ŚMIETAŃSKA I., DO VAN PHI, 1978: Mineralizacja kruszcowa kamienieckiego pasma łupkowego w Górach Izerskich. Prace Nauk. Uniw. Śl., Geologia 3, 243, 7-89.

CHLEBOWSKI R., KOWALSKI W., 1979: Mineralogia. Podręcznik dla Techników Geologicznych. Wyd. Geol. 174 str.

KOWALSKI W., STĘPNIEWSKI M., 1979: X-ray diffraction powder method of determining the composition of strontium-containing barites. Bull. Acad. Pol. Sci., Ser. sci. de la Terre 27, 3-4, 151-157.

KOWALSKI W., PASIECZNA A., 1980: Geochemia boru w osadach karbonu lubelskiego na przykładzie otworu wiertniczego Izdebno IG-1. Arch. Miner. 36, 2, 123-134.

KOWALSKI W., OSMÓLSKI T., PILICHOWSKA E., 1980: Stroncjanit w złożu siarki kopalni Machów. Arch. Miner. 36, 2, 29-50.

SZPILA K., KOWALSKI W., 1980: Syderyty w trzeciorzędowych osadach niecki żytawskiej. Arch. Miner. 36, 2, 5-28.

KOWALSKI W., KARWOWSKI Ł., 1981: Sulfide minerals from the barite-fluorite deposit at Stanisławów in the Kaczawa Mts., Lower Silesia. Acta Geol. Pol. 31, 1-2, 49-58.

KOWALSKI W., ŚMIETAŃSKA I., 1982: Gorceixite from barite-fluorite deposit at Stanisławów. Miner. Polon. 13, 1, 3-20.

KOWALSKI W., CHLEBOWSKI R., ŻELICHOWSKI A., 1982: Charakterystyka mineralogiczno-petrograficzna utworów karbonu rowu mazowiecko-lubelskiego. Bull. Geol. UW 25, 165-263.

ŻELICHOWSKI A., CHLEBOWSKI R., GROTEK L., KMIECIK W., KOWALSKI W., WOJCZYŃSKI S., 1983: Osady karbonu w strefie uskoku Grójca. Bull. IG 344, 25.

KOWALSKI W., PARAFINIUK J., HAŁAS S., 1990: Model of sulfur isotope fractionation in the Polish native sulfur deposits. Freiberger Forschungsh. C441, 65-77.

KOWALSKI W., POLAŃSKI A., 1990: Minerały i złoża pierwiastków ziem rzadkich. W: Pierwiastki ziem rzadkich - surowce, technologie, zastosowania. Wyd. Nauk.-Techn., Warszawa, 165-263.

KOWALSKI W., PARAFINIUK J., STĘPISIEWICZ M., 1991: Mineralogia i geochemia fosfogipsów z hałdy Zakładów Chemicznych Wizów. Arch. Miner. 45, 1-2, 115-134.

PARAFINIUK J., KOWALSKI W., HAŁAS S., 1994: Stable isotope geochemistry and the genesis of the Polish native sulphur deposits - a review. Kwart. Geol. 38, 3, 473-496.

KOWALSKI W., BŁASZCZYK M., MYCIELSKI R., PRZYTOCKA-JUSIAK M., RZECZYCKA M. 1997: Microbiological recovery of lanthanides from phosphogypsum waste. ICAM 96 - Proceedings of the International Congress on Applied Mineralogy in the Mineral Industry, Warsaw, 221-228. 
CHLEBOWSKI R., KOWALSKI W., 1999: Petrographic and mineralogical studies of contemporary sediments developed on the wreck of a ship on the Baltic Sea bottom. Arch. Miner. 52, 2, 141-162.

KOWALSKI W., WOLICKA D., HOŁUB W., PRZYTOCKA-JUSIAK M., 2000: Biotransformacja fosfogipsu $\mathrm{w}$ hodowlach beztlenowej mikroflory namnażanej z różnych środowisk na podłożach $\mathrm{z}$ etanolem. Zesz. Nauk. Politechn. Śl. 45, 211-219.

RZECZYCKA M., MYCIELSKI R., KOWALSKI W., GAŁAZZKA M., 2001: Biotransformation of phosphogypsum in media containing different forms of nitrogen. Acta Microbiol. Polon. 50, 3-4, 281-289.

KOWALSKI W., PRZYTOCKA-JUSIAK M., BŁASZCZYK M., HOŁUB W., WOLICKA D.,WESOŁOWSKA I., 2002: Effect of nitrates on biotransformation of phosphogypsum and phenol uptake in cultures of autochthonous sludge microflora from pertoleum refining wastewaters. Acta Microbiol. Polon. 51, 47-56.

WOLICKA D., KOWALSKI W., BOSZCZYK-MALESZAK H., 2005: Utilization of different carbon compounds by sulphate-reducing bacteria in mediums with phosphogypsum. Arch. Environ. Prot. 31, 2, 105-112. 